STUDIA PRAWNO-EKONOMICZNE, T. CXI, 2019

PL ISSN 0081-6841; e-ISSN 2450-8179 $\quad$ s. 79-95

https://doi.org/10.26485/SPE/2019/111/5

\title{
Kamila SOBIERAJ*
}

iD https://orcid.org/0000-0001-6432-4977

\section{UTWORZENIE PAŃSTWOWEGO GOSPODARSTWA WODNEGO „WODY POLSKIE” JAKO PRZEJAW KONCENTRACJI ZADAŃ I KOMPETENCJI W OBSZARZE GOSPODARKI WODNEJ - WYBRANE ZAGADNIENIA}

(Streszczenie)

Ustawa z 20.07.2017 r. - Prawo wodne, która weszła w życie 1.01.2018 r., wprowadziła zmianę struktury organizacyjno-prawnej oraz podziału zadań i kompetencyjnej organów właściwych w sprawach gospodarowania wodami. Powołana została nowa struktura - Państwowe Gospodarstwo Wodne „Wody Polskie” (WP). WP są ujednoliconą strukturą instytucjonalną, która zastąpiła co do zasady dotychczasowe organy działające w obszarze gospodarowania wodami i skupiła szeroką grupę wyspecjalizowanych i sprofilowanych zadań i kompetencji z tego obszaru. Skoncentrowaniu uległo kilka rodzajów zadań i kompetencji w obszarze gospodarowania wodami dotychczas rozproszonych pomiędzy wieloma pomiotami i powierzonych w dużej części ogólnym organom administracji publicznej.

Celem artykułu jest analiza wybranych zadań i kompetencji z zakresu gospodarki wodnej, które uległy koncentracji: wydawanie zgód wodnoprawnych oraz skoncentrowanie w rękach WP rozstrzygania zagadnień wymagających wysoko wyspecjalizowanej wiedzy z zakresu gospodarowania wodami występujących w innych postępowaniach.

Artykuł zmierza do wykazania, że choć zmiany te niewątpliwie mogą mieć istotne znaczenie dla usprawnienia i przyspieszenia przebiegu procesu inwestycyjnego w obszarze gospodarowania wodami, występowanie pewnych niejednoznaczności, nieprecyzyjności w relacji pomiędzy przepisami, ich wzajemna niespójność przysporzyć mogą organom i inwestorom zobowiązanym do ich stosowania problemów, a przez to stopień osiągnięcia zamierzonego skutku może być mniejszy. Zasadne jest też rozważenie wprowadzenia dodatkowych regulacji.

Słowa kluczowe: organy wyspecjalizowane; zadania publiczne; efektywność działania administracji publicznej

* Dr nauk prawnych, Katolicki Uniwersytet Lubelski Jana Pawła II, Wydział Prawa, Prawa Kanonicznego i Administracji, Katedra Prawa Zarządzania Środowiskiem; e-mail: sobieraj@kul.pl 


\section{Wstęp}

System organów gospodarowania wodami, w tym model podziałów i powiązań kompetencyjnych między tymi organami, był systemem złożonym, rozbudowanym, podlegającym zasadzie decentralizacji i subsydiarności. Powyższe często niekorzystnie oddziaływało na efektywność, skuteczność oraz prawidłowość realizacji zadań publicznych w obszarze gospodarki wodnej. Jednocześnie obszar gospodarki wodnej jako wysoko wyspecjalizowany obszar ochrony środowiska ${ }^{1}$ już od pewnego czasu coraz bardziej wyróżniał się konsekwentnym dążeniem ustawodawcy do porządkowania oraz koncentrowania zadan i kompetencji w rękach wyspecjalizowanych organów (czemu towarzyszyła postępująca marginalizacja organów jednostek samorządu terytorialnego). Ustawa z 20 lipca 2017 r. - Prawo wodne ${ }^{2}$ powołująca Państwowe Gospodarstwo Wodne „Wody Polskie” (WP), jako ujednoliconą strukturę instytucjonalną, zastępującą co do zasady dotychczasowe organy i skupiającą szeroką grupę wyspecjalizowanych i sprofilowanych zadań i kompetencji z zakresu gospodarki wodnej, stanowi kolejny ważny etap w tym procesie.

Celem artykułu jest analiza wybranych zadań i kompetencji z zakresu gospodarki wodnej, które uległy koncentracji w związku z wejściem w życie upw. Są to wydawanie zgód wodnoprawnych oraz skoncentrowanie w rękach WP rozstrzygania zagadnień wymagających wysoko wyspecjalizowanej wiedzy z zakresu gospodarowania wodami, występujących w innych postępowaniach. Artykuł zmierza do wykazania, że choć wprowadzone zmiany mogą mieć istotne znaczenie dla usprawnienia i przyspieszenia przebiegu procesu inwestycyjnego w obszarze gospodarowania wodami, występowanie pewnych niespójności w relacji pomiędzy przepisami może spowodować, że stopień osiągnięcia zamierzonego skutku może być mniejszy. Celem artykuł jest włączenie się w dyskusję na temat potrzeby stworzenia bardziej efektywnego modelu powiązań kompetencyjnych w obszarze ochrony środowiska, w tym gospodarowania wodami, a w konsekwencji zwiększenia efektywności i merytorycznej poprawności działań administracji w tym obszarze. Artykuł może stać się też przyczynkiem do dalszych badań w zakresie poprawy efektywności funkcjonowania nowo utworzonych WP.

Jednocześnie należy wskazać, że analizowane kompetencje i zadania nie są jedynymi, których próby skoncentrowania podjął się ustawodawca. Można też wskazać na kompetencje i zadania z zakresu wykonywania praw właści-

T. Tuszko, Gospodarka wodna a środowisko, Ludowa Spółdzielnia Wydawnicza, Warszawa 1984, s. 16; M. Górski, A. Kaźmierska-Patrzyczna, Gospodarka wodami śródlądowymi, w: M. Górski (red.), Prawo ochrony środowiska, Wolters Kluwer, Warszawa 2014, s. 393.

2 Tj. Dz.U. z 2018 r., poz. 2268 ze zm., dalej: upw. 
cielskich wód Skarbu Państwa. Istotne jest też skoncentrowanie (wzmocnienie) zadań i kompetencji nadzorczych ministra właściwego ds. gospodarki wodnej wobec WP (zapewnienie ministrowi wpływu na działalność WP jako całości, na wszystkie jej jednostki, nie tylko na Prezesa WP) oraz skoncentrowanie zwierzchnictwa ministra nad obszarem planistycznym w zakresie gospodarki wodnej (przejęcie od RM). Ważne jest też skoncentrowanie kompetencji i zadań planistycznych w ramach WP (skupienie w rękach Prezesa WP kompetencji i zadań dotychczas dzielonych pomiędzy Prezesem Krajowego Zarządu Gospodarki Wodnej (KZGW) a dyrektorem regionalnego zarządu gospodarki wodnej (RZGW). Analiza wszystkich obszarów koncentracji kompetencji i zadań ze względu na ograniczone ramy artykułu nie jest możliwa.

Odnosząc się do struktury artykułu, wskazać trzeba, że punkt 2 zmierza do zarysowania tendencji, które do 31.12.2017 r. kształtowały model podziałów i powiązań kompetencyjnych organów działających w obszarze gospodarki wodnej. Przedmiotem punktu 3 jest kwestia skoncentrowania od 1.01.2018 r. w rękach WP wydawania zgód wodnoprawnych. W ramach punktu 4 przeanalizowana została kwestia włączenia WP do innych postępowań wymagających wiadomości specjalnych z zakresu gospodarki wodnej.

Ze względu na to, że upw weszła w życie niedawno, brak jest tego rodzaju analiz. Opublikowane artykuły dotyczą dotychczasowej struktury organów działających w obszarze gospodarki wodnej ${ }^{3}$.

Autorka termin „koncentracja zadań i kompetencji” rozumie jako skupienie zadań i kompetencji w rekach jednego lub nielicznej grupy organów ${ }^{4}$. Autorka nie podjęła się analizy terminologicznej pojęć „,gospodarka wodna”, „gospodarowanie wodami”, oraz „kompetencja” a „zadanie”. Kwestie te zostały omówione w literaturze, a konstrukcja tych pojęć nie uległa zmianie. Podstawową metodę badawczą stanowi metoda dogmatyczno-prawna.

3 M. Walas, Organy i stużby ochrony wód, w: B. Rakoczy (red.), Wybrane problemy prawa wodnego, Wolters Kluwer, Warszawa 2013, s. 265-288.

4 E. Olejniczak-Szałowska, Zasady centralizacji i decentralizacji oraz koncentracji i dekoncentracji, w: M. Stahl (red.), Prawo administracyjne: Pojęcia, instytucje, zasady $w$ teorii i orzecznictwie, Warszawa 2013, s. 180.

5 Analiza pojęć: B. Rakoczy, Wprowadzenie do prawa wodnego, w: B. Rakoczy (red.), Wybrane problemy prawa wodnego, Wolters Kluwer, Warszawa 2013, s. 15-26; J. Rotko, Podstawy prawne gospodarki wodnej, Wydawnictwo Uniwersytetu Wrocławskiego, Wrocław 2006, s. 10.

6 „Kompetencja” oznacza „uprawnienie do zastosowania przez dany organ określonych środków działania, umożliwiających zrealizowanie nałożonych zadań" - A. Barczak, E. Kowalewska, Zadania samorzadu terytorialnego w ochronie środowiska. Aspekty materialne i finansowe, Warszawa 2015, s. 21. Analiza tych pojęć: J. Zimmermann, Prawo administracyjne, Warszawa 2014, s. 142-144 (Kompetencje organu administracji publicznej). 


\section{Tendencje wpływające na dotychczasowy model podziałów i powiązań kompetencyjnych}

Kształtujący się na przestrzeni kilkunastu lat system organów gospodarowania wodami był systemem o złożonych i skomplikowanych powiązaniach kompetencyjnych. Polski prawodawca przyjął tzw. mieszaną koncepcję systemu organów gospodarowania wodami (przyznał kompetencje do załatwienia tych spraw istniejącym ogólnym organom administracji różnych szczebli oraz organom wyspecjalizowanym). Był to minister właściwy do spraw gospodarki wodnej, Prezes KZGW, dyrektor RZGW, wojewoda, organy jednostek samorządu terytorialnego, ale też inne: organy ochrony środowiska niewyspecjalizowane w obszarze gospodarowania wodami (np. organy Inspekcji Ochrony Środowiska, regionalny dyrektor ochrony środowiska), ogólne organy administracji rządowej (np. RM). Tak ukształtowany system organów działających w obszarze gospodarki wodnej był tworzony pod wpływem ujętej w Konstytucji $\mathrm{RP}^{7}$ zasady decentralizacji ${ }^{8}$ oraz zasady subsydiarności. Niestety zasady te zostały często zastosowane,,automatycznie" (tj. bez należytego rozważenia możliwości sprawnego i prawidłowego wykonywania zdań') też w wielu sprawach wymagających specjalistycznej wiedzy, którą nie dysponują organy samorządu terytorialnego. „Zrekompensowaniu” powierzania rozstrzygania spraw, wymagających dla ich merytorycznej poprawności wiedzy fachowej, ogólnym organom samorządu terytorialnego wydawały się służyć instrumenty współdziałania polegające na opiniowaniu, uzgadnianiu lub wyrażaniu zgody. Jednak często nieodpowiednie skonstruowanie i nadmierne stosowanie tych instytucji, w szczególności w bardzo wyspecjalizowanych sprawach z zakresu ochrony środowiska, skutkowało negatywnymi konsekwencjami ${ }^{10}$. Dużej liczbie organów często działających na

Konstytucja Rzeczypospolitej Polskiej z 2.04.1997 r. (Dz.U. z 1997 r., nr 78, poz. 483 ze zm.).

8 Szerzej: E.J. Nowacka, Samorząd terytorialny jako forma decentralizacji administracji publicznej, LexisNexis, Warszawa 2010, s. 15-31; K. Marszal, Wptyw czynników zewnętrznych na samorzą terytorialny - analiza czynników ograniczających samodzielność jednostek samorząu terytorialnego, w: B. Dolnicki, J.P. Tarno (red.), Samorzą terytorialny w Polsce a samorzadowa kontrola administracji, Wolters Kluwer, Warszawa 2012, s. 230-235; D. Dąbek, J. Zimmermann, Decentralizacja poprzez samorzad terytorialny $w$ ustawodawstwie i orzecznictwie pokonstytucyjnym, w: P. Sarnecki (red.), Samorzad terytorialny. Zasady ustrojowe i praktyka, Wydawnictwo SGH, Warszawa 2005, s. 7-10.

9 G. Dobrowolski, Organy właściwe do wydania decyzji o środowiskowych uwarunkowaniach, w: E. Ura, J. Stelmasiak, S. Pieprzny (red.), Ocena modelu prawnego organizacji ochrony środowiska w Polsce i na Stowacji, Wydawnictwo RS Druk, Rzeszów 2012, s. 281.

10 M. Górski, W poszukiwaniu modelu administrowania sprawami ochrony środowiska w Polsce, w: J. Supernat (red.), Między tradycją a przyszłościa w nauce prawa administracyjnego. 
różnych szczeblach administracji (również ogólnych organów samorządu terytorialnego), zaangażowanych w wykonywanie specjalistycznych zadań z zakresu gospodarki wodnej towarzyszył często brak należytej koordynacji zadań i kompetencji, co zauważyć można w co najmniej trzech sytuacjach.

Po pierwsze, należy zwrócić uwagę na przypisywanie różnym podmiotom kompetencji nadzorczych nad tym samym organem, co mogło prowadzić do rozmywania się nadzoru, ale też skutkować osłabieniem pozycji ustrojowej nadzorowanego organu. Do dnia 31.12.2017 r. przykładem powyższego w obszarze gospodarki wodnej był Prezes KZGW i kierowany przez niego urząd, wobec którego kompetencje nadzorcze posiadał zarówno minister właściwy do spraw gospodarki wodnej (głównie zwierzchnictwo organizacyjne), jak i Prezes RM, który powoływał i odwoływał Prezesa KZGW (zwierzchnictwo personalne).

Po drugie, wskazać trzeba na powierzanie tego samego rodzaju zadań wymagających wyspecjalizowanej wiedzy różnym organom - głównie organom ogólnym nieposiadającym takiej wiedzy i obarczonym też szeregiem innego rodzaju zadań. Do dnia 31.12.2017 r. przykładem tego w obszarze gospodarki wodnej była kwestia wydawania pozwoleń wodnoprawnych. W myśl art. 140 ust. 1 ustawy z 18.07.2001 r. - Prawo wodne ${ }^{11}$ organem właściwym do wydawania pozwoleń wodnoprawnych był co do zasady starosta. Przy czym, mając na uwadze wysokie wyspecjalizowanie obszaru gospodarki wodnej, w postanowieniach dawnej upw widoczny był już pewien stopień marginalizacji organów samorządu terytorialnego. Starosta wydawał pozwolenia wodnoprawne jako zadanie z zakresu administracji rządowej, czego konsekwencją było to, że odwołanie od tych pozwoleń rozpoznawał dyrektor RZGW, a nie samorządowe kolegium odwoławcze ${ }^{12}$. W sytuacjach wymienionych w ust. 2 art. 140 dawnej upw organem właściwym do wydawania pozwoleń wodnoprawnych był marszałek województwa, a w ust. 2a-dyrektor RZGW. Wykonywanie zadania w zakresie wydawania pozwoleń wodnoprawnych realizowane było w układzie zdecentralizowanym przez kilka organów, co do zasady organów niewyspecjalizowanych w problematyce gospodarowania wodami.

Księga jubileuszowa dedykowana Profesorowi Janowi Bociowi, Wydawnictwo Uniwersytetu Wrocławskiego, Wrocław 2009, s. 183; M. Szalewska, Współdziałanie organów administracji publicznej w procedurze wydawania decyzji o środowiskowych uwarunkowaniach przedsięwzięcia, w: B. Rakoczy (red.), Oceny oddziatywania na środowisko w praktyce, Wolters Kluwer, Warszawa 2017, s. 117-118.

11 Tj. Dz.U. z 2017 r., poz. 1121 ze zm.; dalej jako: dawna upw.

12 A. Barczak, Zadania o charakterze reglamentacyjno-zobowiazujacym, w: A. Barczak, E. Kowalewska, Zadania samorządu terytorialnego w ochronie środowiska. Aspekty materialne i finansowe, Wolters Kluwer, Warszawa 2015, s. 134. 
Brak należytej koncentracji powierzanych kompetencji i zadań przejawiał się też w przyznawaniu jednemu organowi zadań o zupełnie odmiennym charakterze. Do dnia 31.12.2017 r. przykładem powyższego w obszarze gospodarki wodnej był zakres kompetencji i zadań przydzielony dyrektorowi RZGW. Organ ten wykonywał zadania, które można zaliczyć do zadań organizatorskich z zakresu planowania (np. art. 92 ust. 3 pkt 6 i 6a dawna upw), zadań z zakresu wykonywania kontroli gospodarowania wodami (art. 92 ust. 3 pkt 12 dawna upw), wydawania w sytuacjach wskazanych w ustawie pozwoleń wodnoprawnych oraz zadań z zakresu zarządzania majątkiem SP (art. 92 ust. 4 dawna upw).

Dnia 20.07.2017 r. uchwalona została upw, która m.in. wprowadziła zmianę struktury organizacyjno-prawnej oraz kompetencyjnej organów właściwych w sprawach gospodarowania wodami. Zlikwidowany został urząd Prezesa KZGW jako centralnego organu administracji rządowej oraz dyrektorów RZGW jako terenowych organów administracji rządowej, podlegających Prezesowi KZGW. Powołane zostały WP jako państwowa osoba prawna podległa wyłącznie ministrowi właściwemu do spraw gospodarki wodnej. Skoncentrowanie w rękach jednego podmiotu wyspecjalizowanych zadań w zakresie gospodarki wodnej powinno zagwarantować wysoki stopnień poprawności formalnoprawnej przeprowadzanych procedur, związanych z realizacją inwestycji w obszarze gospodarki wodnej oraz materialnej podejmowanych rozstrzygnięć, a w konsekwencji zmniejszyć ryzyko ich kwestionowania przed sądami.

\section{Wydawanie zgód wodnoprawnych}

Upw przewiduje cztery rodzaje zgód wodnoprawnych: pozwolenie wodnoprawne; zgłoszenie wodnoprawne; ocena wodnoprawna oraz decyzje uregulowane w art. 77 ust. 3 (zwolnienie na obszarach szczególnego zagrożenia powodzią od zakazu gromadzenia ścieków, odchodów zwierzęcych, środków chemicznych, innych substancji lub materiałów, które mogą zanieczyścić wody; prowadzenia odzysku lub unieszkodliwiania odpadów; lokalizowania cmentarzy) i ust. 8 (zwolnienie od zakazu poruszania się określonymi pojazdami po wodach powierzchniowych oraz gruntach pokrytych wodami) oraz w art. 176 ust. 4 upw (zwolnienie od zakazu wykonywania na wałach przeciwpowodziowych obiektów lub urządzeń niezwiązanych z nimi funkcjonalnie).

Kompetencje i zadania z zakresu wydawania zgód wodnoprawnych zostały przypisane trzem organom WP: dyrektorowi RZGW WP, dyrektorowi zarządu zlewni oraz kierownikowi nadzoru wodnego (art. 397 ust. 1 upw), a gdy 
wnioskodawcą są WP - ministrowi właściwemu do spraw gospodarki wodnej. W konsekwencji ograniczeniu uległy kompetencje organów samorządu terytorialnego, głównie starostów. Można stwierdzić, że upw stanowi „dopełnienie” postępującego procesu marginalizacji organów samorządu terytorialnego w zakresie kompetencji i zadań odnośnie do reglamentacji korzystania z wód.

Pozytywnie należy ocenić koncentrację w rękach wyspecjalizowanej jednostki WP (rozproszonych uprzednio między organami różnych szczebli i charakteru) kompetencji i zadań w zakresie wydawania pozwoleń wodnoprawnych. Również nowy rodzaj zgód wodnoprawnych (oceny wodnoprawne) został powierzony WP. Wskazać trzeba na fakt, że wydanie zgód wodnoprawnych wymaga wyspecjalizowanej wiedzy z zakresu wielu obszarów gospodarki wodnej.

Przed wydaniem pozwolenia wodnoprawnego organ zobowiązany jest zweryfikować zgodność zamierzonej przez wnioskodawcę inwestycji lub działania m.in. z ustaleniami planu gospodarowania wodami na obszarze dorzecza; planów ochrony i planów zadań ochronnych dla obszarów chronionych; planu zarządzania ryzykiem powodziowym; planu przeciwdziałania skutkom suszy; programu ochrony wód morskich (art. 396 ust. 1 upw), które opracowywane są przez $\mathrm{WP}^{13}$. Obszerność i złożoność specjalistycznych ustaleń zawartych przez WP $\mathrm{w}$ dokumentach planistycznych z zakresu gospodarki wodnej nasuwać może wątpliwości co do merytorycznej zdolności starosty do ich prawidłowego zweryfikowania. $Z$ kolei przedmiotem oceny wodnoprawnej jest analiza wpływu planowanej inwestycji lub działania na możliwość osiągnięcia celów środowiskowych dla wód wymienionych w art. 56, art. 57, art. 59 oraz w art. 61 (art. 429 upw) $)^{14}$. Jeżeli ustalono, że planowana inwestycja lub działanie wpływa negatywnie na możliwość osiągnięcia celów środowiskowych dla wód, organ właściwy w sprawach ocen wodnoprawnych nakłada obowiązek przedłożenia dokumentów potwierdzających spełnienie warunków z art. 68 pkt 1, 3 i 4 (art. 432 upw), czego zweryfikowanie wymaga specjalistycznej wiedzy z zakresu gospodarki wodnej.

13 Odnośnie do pozwoleń wodnoprawnych do 31.12.2017 r.: M. Benke, Pozwolenie wodnoprawne jako prawny instrument ochrony środowiska, w: B. Rakoczy, M. Pchalek (red.), Problemy prawa ochrony środowiska, Wolters Kluwer, Warszawa 2010, s. 175-181. K. Chochowski, Pozwolenie wodnoprawne jako instrument ochrony środowiska, w: B. Jeżyńska, E. Kruk (red.), Prawne instrumenty ochrony środowiska, Wydawnictwo UMCS, Lublin 2016, s. 162-170.

14 Na temat oceny wodnoprawnej: P. Ćwiek, Ocena wodnoprawna-nowe obowiązi inwestora, w: A. Cybulska, P. Ćwiek, L. Osuch-Chaciński, E. Piętowska, M. Stachowska, M. Wyszogrodzki, Nowe prawo wodne. Omówienie. Pytania i odpowiedzi. Tekst ustawy, Wolters Kluwer, Warszawa 2017, s. 11-20. 
Nieprawidłowości w zakresie poczynionych przez organy wydające zgody wodnoprawne ustaleń i wniosków może mieć negatywne konsekwencje w przypadku, gdy dotyczą one procesu inwestycyjnego z zakresu gospodarki wodnej. Rozstrzygnięcia budzące wątpliwości co do ich materialnej i proceduralnej prawidłowości mogą być zaskarżane, co doprowadzić może do przedłużania całego procesu inwestycyjnego. Zezwolenie lub innego rodzaju zgoda obarczona wadą prawną stanowić mogą zaś dla inwestora ryzyko, że pomimo ich wejścia do obrotu prawnego mogą zostać uchylone, co zablokuje rozpoczęty proces inwestycyjny.

Następną kwestią wartą zaznaczenia jest wprowadzenie przez upw instrumentów koordynacji kompetencji organów WP w zakresie wydawania zgód wodnoprawnych lub postępowań w sytuacji, gdy wnioskodawca będzie zobowiązany do uzyskania co najmniej dwóch takich zgód (upw przewiduje cztery rodzaje zgód wodnoprawnych, a powierza ich wydanie trzem organom WP). Niestety mają one bardzo ograniczoną formułę. Pierwszy instrument koordynacji procedur polega na tym, że jeden organ przejmuje na mocy ustawy kompetencje innego organu, ale przeprowadzane są dwa odrębne postępowania. W myśl art. 397 ust. 5 upw organem właściwym w sprawach ocen wodnoprawnych jest organ właściwy w sprawach pozwoleń wodnoprawnych. Inny instrument dotyczy połączenia dwóch postępowań (w jedno) i wydania jednej decyzji. Zgodnie z art. 427 ust. 2 upw, jeżeli jest wymagane uzyskanie oceny wodnoprawnej oraz decyzji, o której mowa w art. 77 ust. 3, sprawy rozpoznaje się łącznie i wydaje się jedną decyzję.

W ramach upw wprowadzona zostaje też „namiastka” punktu kompleksowej obsługi administracyjnej. Niestety ograniczony jest zakres zadań, zasadna wydaje się analiza co do jego poszerzenia. Według dyspozycji art. 397 ust. 6 upw wniosek o wydanie pozwolenia wodnoprawnego, oceny wodnoprawnej, decyzji, o których mowa w art. 77 ust. 3 i 8 oraz w art. 176 ust. 4, a także zgłoszenia wodnoprawnego składa się w siedzibie nadzoru wodnego. Zaznaczyć należy, że wprowadzanie jednego punktu obsługi administracyjnej jest częste w prawodawstwie państw członkowskich UE, w szczególności w zakresie procesu inwestycyjnego dotyczącego OZE ${ }^{15}$ (też energii wodnej). Na takie jednostki nakładane jest jednak co najmniej zadanie przeprowadzenia wnioskodawcy przez

15 Szerzej: K. de Graff, A. Marseille, Towards efficient administrative procedures for renewable energy projects? The Dutch experience with the Crisis and Recovery Act, w: M. Peeters, T. Schomerus (eds.), Renewable Energy Law in the EU: Legal Perspectives on Bottom up-approaches, Edward Elgar Publishing, Cheltenham-Northampton 2014, s. 128-133; K. de Graaf, H. Tolsma, Country Report: The Netherlands. The Future Environment and Planning Act and the Impact of the Crisis and Recovery Act, IUCN Academy of Environmental Law e-Journal 
wszystkie procedury zezwoleń koniecznych w danym procesie inwestycyjnym, w tym udzielanie wszelkich niezbędnych informacji.

\section{Włączenie WP do innych procedur wymagających wiadomości specjalnych}

W związku z wejściem w życie upw doszło do skoncentrowania w rękach WP kompetencji i zadań w zakresie oceny negatywnego oddziaływania przedsięwzięcia na możliwość osiągnięcia celów środowiskowych dla wód, też przesłanek zawartych w art. 68 pkt 1, 3 i 4 upw. Niezależnie od tego, czy ta ocena jest przeprowadzana $\mathrm{w}$ związku $\mathrm{z}$ wydawaniem decyzji w przedmiocie oceny wodnoprawnej, czy w związku z wydawaniem decyzji o środowiskowych uwarunkowaniach dokonywana jest ona przez dyrektora RZGW WP. Tym samym od dokonania tej oceny odciążone zostały organy wydające decyzję o środowiskowych uwarunkowaniach (niewyspecjalizowane w zakresie gospodarki wodnej).

Zgodnie z dyspozycją art. 71 ust. 2 w zw. z art. 72 ust. 1 pkt 6 ustawy z 3.10.2008 r. o udostępnianiu informacji o środowisku i jego ochronie, udziale społeczeństwa w ochronie środowiska oraz o ocenach oddziaływania na środowisko ${ }^{16}$ przed uzyskaniem pozwolenia wodnoprawnego na wykonanie urządzeń wodnych wymagane jest uzyskanie decyzji o środowiskowych uwarunkowaniach, ale pod warunkiem, że przedsięwzięcie to zaliczone zostanie albo do przedsięwzięć mogących zawsze, albo potencjalnie znacząco oddziaływać na środowisko. Według zasady wprowadzonej przez upw obowiązek wydania decyzji o środowiskowych uwarunkowaniach wyłącza obowiązek uzyskania decyzji w przedmiocie oceny wodnoprawnej. W takiej sytuacji ocena możliwości osiągnięcia celów środowiskowych dla wód, też przesłanek zawartych $\mathrm{w}$ art. 68 pkt 1, 3 i 4 upw będzie przedmiotem postępowania w sprawie wydania decyzji o środowiskowych uwarunkowaniach.

Zgodnie z art. 81 ust. 3 uuiś w wersji obowiązującej do dnia 31.12.2017 r., jeżeli z oceny oddziaływania przedsięwzięcia na środowisko wynikało, że przedsięwzięcie może spowodować nieosiągnięcie celów środowiskowych zawartych w planie gospodarowania wodami na obszarze dorzecza, organ właściwy do wydania decyzji o środowiskowych uwarunkowaniach odmawia zgody na realizację przedsięwzięcia, o ile nie zachodzą przesłanki z art. 38j. Wówczas żaden z wy-

2015/6/5, s. 301-302; J. Verschuuren, The Dutch Crisis and Recovery Act: Economic Recovery and Legal Crisis?, Potchefstroom Electronic Law Journal 2010/13/5, s. 198.

16 Tj. Dz.U. z 2018 r., poz. 2081 ze zm.; dalej jako: uuiś. 
specjalizowanych organów z zakresu gospodarki wodnej (z wyjątkiem dyrektora obszaru morskiego) nie był organem opiniującym lub uzgadniającym w ramach postępowania $\mathrm{w}$ przedmiocie wydawania decyzji o środowiskowych uwarunkowaniach ani na etapie ustalania warunków realizacji przedsięwzięcia, ani w przypadku przedsięwzięć potencjalnie znacząco oddziałujących na środowisko - na etapie ustalania obowiązku przeprowadzenia oceny oraz ustalenia zakresu raportu. Powyższe ustalenia dokonywał organ, który wydawał decyzję o środowiskowych uwarunkowaniach. Zmiany wprowadzone przez upw do uuiś modyfikują zakres cytowanego wyżej przepisu. Co jednak istotniejsze, upw wprowadza art. 64 ust. 1 pkt 1, art. 70 ust. 1 pkt 4 oraz art. 77 ust. 1 pkt 4 u.u.i.ś., który poszerza katalog organów opiniujących lub uzgadniających o dyrektora RZGW WP.

Kolejną kwestią, na którą należy zwrócić uwagę, jest włączenie WP do procedury sporządzania przez organ wykonawczy gminy projektu miejscowego planu zagospodarowania przestrzennego (dalej miejscowy plan) lub wydawania decyzji o ustaleniu lokalizacji inwestycji celu publicznego lub decyzji o warunkach zabudowy (dalej decyzje lokalizacyjne) jako organu uzgadniającego możliwość, a w przypadku rozstrzygnięcia pozytywnego określającego warunki lub wymagania odnośnie do planowanej zabudowy lub planowanego zagospodarowania terenów położonych na obszarze szczególnego zagrożenia powodzią.

Postanowienia art. 166 ust. 1 pkt 1 upw nałożyły na organ obowiązek uwzględnienia obszarów szczególnego zagrożenia powodzią $\mathrm{w}$ określonych $\mathrm{w}$ tym przepisie dokumentach strategicznych, m.in. w miejscowym planie oraz decyzjach lokalizacyjnych. Zaznaczyć należy, że podobne postanowienia, z zastrzeżeniem, że miały one formę „nakazu” albo „możliwości”, funkcjonowały już przed wejściem w życie upw. Wówczas jednak uznanie danego obszaru za obszar szczególnego zagrożenia powodziowego w mapach zagrożenia powodziowego i mapach ryzyka powodziowego skutkowało tym, że na danym obszarze obowiązywały zakazy określone w art. 881 ust. 1 dawnej upw (m.in. zakaz wykonywania urządzeń wodnych oraz budowy innych obiektów). Na wniosek inwestora dyrektor RZGW wszczynał odrębne postępowanie, po przeprowadzeniu którego mógł zwolnić inwestora od tych zakazów.

Obecnie brak jest co do zasady (odgórnego ustawowego) zakazu wykonywania urządzeń wodnych oraz budowy innych obiektów budowlanych na obszarach szczególnego zagrożenia powodzią. Wprowadzona została natomiast instytucja współdziałania ${ }^{17}$ podczas procedury sporządzania projektu miejsco-

17 Pojęcie instytucji współdziałania: J. Zimmermann, Prawo administracyjne, Wolters Kluwer, Warszawa 2012, s. 148-152; S. Biernat, Działania wspólne w administracji państwowej, Zakład Narodowy im. Ossolińskich, Wrocław 1979, s. 83-85. 
wego planu oraz wydawania decyzji lokalizacyjnej, polegająca na uzgadnianiu przez dyrektora RZGW WP możliwości, a w przypadku rozstrzygnięcia pozytywnego określeniu warunków lub wymagań odnośnie do planowanej zabudowy lub zagospodarowania terenów położonych na obszarze szczególnego zagrożenia powodzią. Takie rozwiązanie przyczynić się może do większej pewności i szybkości procesu inwestycyjnego w obszarze gospodarki wodnej. Inwestor nie będzie musiał wszczynać odrębnego postępowania w przedmiocie zwolnienia od wymienionych w dawnej upw zakazów. Niestety kilka kwestii proceduralnych może budzić wątpliwości.

W myśl art. 53 ust. 4 pkt 11(b) ustawy z 27.03.2003 r. o planowaniu i zagospodarowaniu przestrzennym ${ }^{18}$ (w wersji obowiązującej od 1.01.2018 r.) decyzję o lokalizacji inwestycji celu publicznego oraz w związku z art. 64 ust. 1 decyzję o warunkach zabudowy wydaje się po uzgodnieniu z dyrektorem RZGW WP w odniesieniu do obszarów szczególnego zagrożenia powodzią w zakresie warunków zabudowy i zagospodarowania terenu. Uzgodnienie z dyrektorem RZGW WP ma formę decyzji określonej w art. 166 ust. 5 upw (art. 53 ust. 5d upzp). Powyższa forma uzgodnienia jest przepisem szczególnym. Zasadą jest, że uzgodnienia określone w art. 53 ust. 4 upzp mają formę postanowienia, a przeprowadza się je $\mathrm{w}$ trybie kodeksu postępowania administracyjnego ${ }^{19}$.

$\mathrm{Na}$ tym etapie pojawia się wątpliwość odnośnie do charakteru instytucji uzgadniania i wydanej w jego wyniku decyzji. Rozważyć należy, czy jest to instytucja uzgodnienia uregulowana $\mathrm{w}$ art. $106 \S 1 \mathrm{kpa}$ (z zastrzeżeniem, że uzgodnienie ma formę decyzji), czy instytucja zagadnienia wstępnego w rozumieniu art. $97 \S 1$ pkt 4 kpa.

Treść art. 166 ust. 6 upw (stroną postępowania o wydanie decyzji uzgadniającej jest wnioskodawca) skłaniać może do wniosku, że jest to instytucja zagadnienia wstępnego, które powstało w związku z toczącym się postępowaniem administracyjnym w sprawie wydania decyzji lokalizacyjnej. Wówczas na wniosek wnioskodawcy wszczęte zostanie odrębne postępowanie i zostanie wydana decyzja uzgadniająca, będąca decyzją administracyjną w znaczeniu kpa (ew. odmawiająca uzgodnienia). W konsekwencji będzie to sprawa administracyjna w znaczeniu kpa (sprawa indywidualna), a decyzja uzgadniająca będzie mogła być (odrębnie od decyzji lokalizacyjnej) zaskarżona w formie wniesienia odwołania.

Jednak zgodnie $\mathrm{z}$ art. 53 ust. 5 upzp uzgodnień dokonuje się w trybie art. $106 \mathrm{kpa}, \mathrm{z}$ tym że zażalenie przysługuje wyłącznie inwestorowi. Jak

\footnotetext{
18 Tj. Dz.U. z 2018 r., poz. 1945 ze zm.; dalej: upzp.
}

19 Tj. Dz.U. z 2018 r., poz. 2096 ze zm.; dalej: kpa. 
wcześniej zaznaczono, ust. 5d art. 53 upzp wprowadza przepis szczególny, zgodnie z którym uzgodnienie decyzji lokalizacyjnej z dyrektorem RZGW WP w zakresie zabudowy i zagospodarowania terenu położonego na obszarach szczególnego zagrożenia powodzią dokonuje się w drodze decyzji. Pojawić mogą się więc niejasności, czy odpowiednio należy stosować, że środek zaskarżenia od decyzji uzgadniającej może wnieść tylko inwestor, czy też będzie to każdy posiadający interes $\mathrm{w}$ sprawie.

Z kolei analiza art. 53 ust. 5 upzp skłaniać może do innego wniosku - że przedmiotowa instytucja uzgodnienia jest uzgodnieniem w znaczeniu art. $106 \S 1 \mathrm{kpa}$. Jeżeli przyjęte zostanie takie założenie, wniosek o uzgodnienie powinien wnieść organ wykonawczy gminy. Takie twierdzenie będzie sprzeczne $\mathrm{z}$ art. 166 ust. 6 upw (stroną postępowania o wydanie decyzji uzgadniającej jest wnioskodawca). Wydaje się, że przyjęcie założenia, że jest to uzgodnienie w znaczeniu art. $106 \S 1$ kpa wywołać może wątpliwości odnośnie do charakteru decyzji uzgadniającej (czy będzie to decyzja administracyjna w znaczeniu kpa).

Zdecydowanie więcej wątpliwości pojawić się może w związku z uzgadnianiem przez dyrektora RZGW WP projektu miejscowego planu w zakresie określenia warunków lub wymagań odnośnie do planowanej zabudowy lub zagospodarowania terenów położonych na obszarze szczególnego zagrożenia powodzią. Upw wprowadza do art. 17 ust. 6 pkt b upzp dodatkowy organ, z którym organ wykonawczy gminy uzgadnia projekt miejscowego planu. Jest to dyrektor RZGW WP, a uzgodnienie ma dotyczyć zabudowy i zagospodarowania terenu położonego na obszarach szczególnego zagrożenia powodzią. Wszystkie uzgodnienia podczas prac nad projektem miejscowego planu odbywają się w trybie art. $106 \mathrm{kpa}$ (art. 24 ust. 1 zdanie 1 upzp). Przy czym upzp, podobnie jak w przypadku decyzji lokalizacyjnych, również odnośnie do miejscowego planu dodaje do powołanego wyżej artykułu zdanie drugie, zgodnie z którym uzgodnienia projektu planu miejscowego $\mathrm{z}$ dyrektorem RZGW WP w zakresie dotyczącym zabudowy i zagospodarowania terenu położonego na obszarach szczególnego zagrożenia powodzią dokonuje się w drodze decyzji określonej w art. 166 ust. 5 upw. Warto zaznaczyć, że odnośnie do uzgadniania projektu miejscowego planu w literaturze przedmiotu wskazuje się, że art. $106 \mathrm{kpa}$ stosować należy jedynie odpowiednio ${ }^{20}$ (nie jest to postępowanie administracyjne, ale planistyczne). W postępowaniu w sprawie sporządzania projektu planu miejscowego biorą udział podmioty, które nie mają cech strony w ro-

I. Zachariasz, Komentarz do art. 24 ustawy o planowaniu i zagospodarowaniu przestrzennym, LEX 2017. 
zumieniu art. $28 \mathrm{kpa}$. Według wyroku WSA z Warszawy z 5.05.2008 r. zajęcie stanowiska przez inny organ przy sporządzaniu projektu planu miejscowego ma charakter aktu nadzoru nad działalnością gminy przewidzianego przepisami szczególnymi. Środek zaskarżenia na akt wydany przez organ uzgadniający może wnieść jedynie organ wykonawczy gminy, który sporządzał projekt planu miejscowego ${ }^{21}$. W tym kontekście wątpliwości budzi art. 166 ust. 6 upw (stroną postępowania o wydanie decyzji uzgadniającej jest wnioskodawca). Z wnioskiem o uzgodnienie występuje organ wykonawczy gminy. Inwestor nie jest stroną $\mathrm{w}$ procedurze sporządzania projektu planu miejscowego. Postępowanie dotyczące uzgadniania projektu planu miejscowego nie jest postępowaniem administracyjnym, nie jest to sprawa administracyjna (sprawa indywidualna). Wątpliwości pojawić się zatem mogą odnośnie do charakteru decyzji uzgadniającej oraz środka jej zaskarżenia. Nie wydaje się, aby była to decyzja administracyjna.

\section{Zakończenie}

Istotne znaczenie dla usprawnienia i przyspieszenia przebiegu procesu inwestycyjnego w obszarze gospodarowania wodami może mieć nie tylko skoncentrowanie (w wyniku wejścia w życie upw) kompetencji i zadań w zakresie wydawania zgód wodnoprawnych w rękach WP. Wskazać trzeba też na kwestię skoordynowania kompetencji i zadań organów WP lub postępowań, w sytuacji gdy wnioskodawca zobowiązany jest uzyskać co najmniej dwa rodzaje zgód wodnoprawnych. Istotne jest też włączenie WP (głównie dyrektora RZGW WP) poprzez instytucje uzgadniania do innych postępowań, zarówno administracyjnych (wydawanie decyzji o środowiskowych uwarunkowaniach oraz decyzji lokalizacyjnych), jak i planistycznych (sporządzanie miejscowego planu) celem rozstrzygania wynikających w toku tych postępowań kwestii wymagających specjalistycznej wiedzy z zakresu gospodarki wodnej. Skutkiem takiej koncentracji może być: po pierwsze - polepszenie prawidłowości merytorycznej i proceduralnej wykonywania specjalistycznych zadań, a w konsekwencji przyśpieszenie procedur związanych z realizacją inwestycji z zakresu gospodarki wodnej; po drugie - większe ujednolicenie rozstrzygnięć tego samego rodzaju w podobnych sprawach (np. określenia wodnoprawnych uwarunkowań realizacji inwestycji); po trzecie - odciążenie organów ogólnych administracji oraz organów ochrony środowiska niewyspecjali-

${ }^{21}$ Sygn. akt IV SA/Wa 372/08, LEX nr 506934. 
zowanych w zakresie gospodarki wodnej, a przez to zwiększenie efektywności realizacji przez nie innych powierzonych im zadań; po czwarte - koncentracja (a w konsekwencji przyspieszenie) odrębnych postępowań (co do zasady wyłączenie wszczynania odrębnego postępowania w przedmiocie zwolnienia z zakazu realizacji urządzeń wodnych oraz budowy innych obiektów budowlanych na obszarze szczególnego ryzyka powodziowego).

Powyższe wydaje się zwiększać prawdopodobieństwo sprawnego, skutecznego i prawidłowego wykonywania zdań z zakresu gospodarki wodnej przez WP. Należy jednak zaznaczyć, że podejmując próbę przyznania dyrektorowi RZGW WP kompetencji do rozstrzygania kwestii z zakresu gospodarki wodnej w ramach procedur regulowanych w upzp, wydaje się, że ustawodawca nie zdołał ustrzec się sytuacji mogących budzić wątpliwości co do interpretacji wzajemnej korelacji przepisów zawartych w upw oraz upzp. Niejednoznaczność, nieprecyzyjność w relacji pomiędzy przepisami, ich wzajemna niespójność przysporzyć mogą organom i inwestorom zobowiązanym do ich stosowania problemów, a przez to stopień osiągnięcia zamierzonego skutku może być znacznie mniejszy. Zasygnalizowane w artykule wątpliwości o charakterze proceduralnym wymagają dalszych analiz celem ich rozstrzygnięcia. Rozważenia wymaga też wprowadzenie punktu kompleksowej obsługi administracyjnej w ramach procesu inwestycyjnego w zakresie gospodarki wodnej.

\section{Bibliografia}

\section{Akty prawne}

Konstytucja Rzeczypospolitej Polskiej z dnia 2 kwietnia 1997 r. (Dz.U. z 1997 r., nr 78, poz. 483 ze zm.).

Ustawa z dnia 14 czerwca 1960 r. Kodeks postępowania administracyjnego (tj. Dz.U. z 2018 r., poz. 2096 ze zm.).

Ustawa z dnia 18 lipca 2001 r. - Prawo wodne (tj. Dz.U. z 2018 r., poz. 2268 ze zm.).

Ustawa z dnia 27 marca 2003 r. o planowaniu i zagospodarowaniu przestrzennym (tj. Dz.U. z 2018 r., poz. 1945 ze zm.).

Ustawa z dnia 3 października 2008 r. o udostępnianiu informacji o środowisku i jego ochronie, udziale społeczeństwa w ochronie środowiska oraz o ocenach oddziaływania na środowisko (tj. Dz.U. z 2018 r., poz. 2081 ze zm.).

Ustawa z dnia 20 lipca 2017 r. - Prawo wodne (tj. Dz.U. z 2018 r., poz. 2268 ze zm.).

\section{Opracowania}

Barczak Anna, Zadania o charakterze reglamentacyjno-zobowiąującym, w: Anna Barczak, Ewa Kowalewska, Zadania samorzadu terytorialnego w ochronie środowiska. Aspekty materialne i finansowe, Wolters Kluwer, Warszawa 2015, s. 134. 
Barczak Anna, Kowalewska Ewa, Zadania samorządu terytorialnego w ochronie środowiska. Aspekty materialne i finansowe, Wolters Kluwer, Warszawa 2015, s. 21, 134.

Benke Marcin, Pozwolenie wodnoprawne jako prawny instrument ochrony środowiska, w: Bartosz Rakoczy, Marcin Pchałek (red.), Problemy prawa ochrony środowiska, Wolters Kluwer, Warszawa 2010, s. 175-181.

Biernat Stanisław, Działania wspólne w administracji państwowej, Zakład Narodowy im. Ossolińskich, Wrocław 1979, s. 243-255.

Chochowski Krzysztof, Pozwolenie wodnoprawne jako instrument ochrony środowiska, w: Beata Jeżyńska, Emil Kruk (red.), Prawne instrumenty ochrony środowiska, Wydawnictwo UMCS, Lublin 2016, s. 162-170.

Cybulska Agnieszka, Ćwiek Piotr, Osuch-Chaciński Lucjan, Piętowska Ewa, Stachowska Marta, Wyszogrodzki Michal, Nowe prawo wodne. Omówienie. Pytania i odpowiedzi. Tekst ustawy, Wolters Kluwer, Warszawa 2017, s. 11-20.

Ćwiek Piotr, Ocena wodnoprawna - nowe obowiązki inwestora, w: Agnieszka Cybulska, Piotr Ćwiek, Lucjan Osuch-Chaciński, Ewa Piętowska, Marta Stachowska, Michał Wyszogrodzki, Nowe prawo wodne. Omówienie. Pytania i odpowiedzi. Tekst ustawy, Wolters Kluwer, Warszawa 2017, s. 11-20.

Dąbek Dorota, Zimmermann Jan, Decentralizacja poprzez samorząd terytorialny $w$ ustawodawstwie i orzecznictwie pokonstytucyjnym, w: Paweł Sarnecki (red.), Samorząd terytorialny. Zasady ustrojowe i praktyka, Wydawnictwo SGH, Warszawa 2005, s. 7-10.

Dobrowolski Grzegorz, Organy właściwe do wydania decyzji o środowiskowych uwarunkowaniach, w: Elżbieta Ura, Jerzy Stelmasiak, Stanisław Pieprzny (red.), Ocena modelu prawnego organizacji ochrony środowiska w Polsce i na Stowacji, Wydawnictwo RS Druk, Rzeszów 2012, s. 281.

Dolnicki Bogdan, Tarno Jan Pawel (red.), Samorząd terytorialny w Polsce a samorzadowa kontrola administracji, Wolters Kluwer, Warszawa 2012, s. 230-235.

Górski Marek, W poszukiwaniu modelu administrowania sprawami ochrony środowiska w Polsce, w: Jerzy Supernat (red.), Między tradycja a przyszłościa w nauce prawa administracyjnego. Księga jubileuszowa dedykowana Profesorowi Janowi Bociowi, Wydawnictwo Uniwersytetu Wrocławskiego, Wrocław 2009, s. 183.

Górski Marek (red.), Prawo ochrony środowiska, Wolters Kluwer, Warszawa 2014, s. 393.

Górski Marek, Kaźmierska-Patrzyczna Aneta, Gospodarka wodami śródlądowymi, w: Marek Górski (red.), Prawo ochrony środowiska, Wolters Kluwer, Warszawa 2014, s. 393.

Górski Marek, Pchałek Marcin, Radecki Wojciech, Jerzmański Jan, Bar Magdalena, Urban Sergiusz, Jendrośka Jerzy, Prawo ochrony środowiska. Komentarz, C.H. Beck, Warszawa 2014, s. 963-964.

De Graaf Kars, Marseille Albert, Towards efficient administrative procedures for renewable energy projects? The Dutch experience with the Crisis and Recovery Act, w: Marjan Peeters, Thomas Schomerous (eds.), Renewable Energy Law in the EU: Legal Perspectives on Bottom up-approaches, Edward Elgar Publishing, Northampton-Massachusetts 2014, s. $128-133$.

De Graff Kars, Tolsma Hanna, Country Report: The Netherlands. The Future Environment and Planning Act and the Impact of the Crisis and Recovery Act, IUCN Academy of Environmental Law e-Journal 2015/6/5, s. 301-302. 
Jaśkowska Małgorzata, Wróbel Andrzej, Komentarz aktualizowany do art. 1 do ustawy z dnia 14 czerwca 1960 r. Kodeks postępowania administracyjnego, LEX/el 2015.

Jeżyńska Beata, Kruk Emil (red.), Prawne instrumenty ochrony środowiska, Wydawnictwo UMCS, Lublin 2016, s. 162-170.

Marszal Katarzyna, Wpływ czynników zewnętrznych na samorząd terytorialny - analiza czynników ograniczających samodzielność jednostek samorządu terytorialnego, w: Bogdan Dolnicki, Jan Paweł Tarno (red.), Samorzad terytorialny w Polsce a samorzadowa kontrola administracji, Wolters Kluwer, Warszawa 2012, s. 230-235.

Nowacka Ewa J., Samorzad terytorialny jako forma decentralizacji administracji publicznej, Wydawnictwo Prawnicze LexisNexis, Warszawa 2010, s. 15-31.

Olejniczak-Szałowska Ewa, Zasady centralizacji $i$ decentralizacji oraz koncentracji i dekoncentracji, w: Małgorzata Stahl (red.), Prawo administracyjne: Pojęcia, instytucje, zasady w teorii i orzecznictwie, Wolters Kluwer, Warszawa 2013, s. 180.

Peeters Marjan, Schomerous Thomas (eds.), Renewable Energy Law in the EU: Legal Perspectives on Bottom up-approaches, Edward Elgar Publishing, Cheltenham-Northampton 2014, s. $128-133$.

Radecki Wojciech (red.), Instytucje prawa ochrony środowiska. Geneza, rozwój, perspektywy, Difin, Warszawa 2010, s. 131-133.

Rakoczy Bartosz, Wprowadzenie do prawa wodnego, w: Bartosz Rakoczy (red.), Wybrane problemy prawa wodnego, Wolters Kluwer, Warszawa 2013, s. 15-26.

Rakoczy Bartosz (red.), Oceny oddziaływania na środowisko w praktyce, Wolters Kluwer, Warszawa 2017, s. 117-118.

Rakoczy Bartosz (red.), Wybrane problemy prawa wodnego, Wolters Kluwer, Warszawa 2013, s. $265-288$.

Rakoczy Bartosz, Pchalek Marcin (red.), Problemy prawa ochrony środowiska, Wolters Kluwer, Warszawa 2010, s. 175-181.

Rotko Jerzy, Podstawy prawne gospodarki wodnej, Wydawnictwo Uniwersytetu Wrocławskiego, Wrocław 2006, s. 10.

Sarnecki Pawel (red.), Samorzą terytorialny. Zasady ustrojowe i praktyka, Wydawnictwo SGH, Warszawa 2005, s. 7-10.

Sommer Jerzy, Planowanie w ochronie środowiska, w: Wojciech Radecki (red.), Instytucje prawa ochrony środowiska. Geneza, rozwój, perspektywy, Difin, Warszawa 2010, s. 131-133.

Stahl Malgorzata (red.), Prawo administracyjne: Pojęcia, instytucje, zasady w teorii i orzecznictwie, Wolters Kluwer, Warszawa 2013, s. 180.

Supernat Jerzy (red.), Między tradycją a przyszłościa w nauce prawa administracyjnego. Księga jubileuszowa dedykowana Profesorowi Janowi Bociowi, Wydawnictwo Uniwersytet Wrocławski, Wrocław 2009, s. 183.

Szalewska Malgorzata, Współdziałanie organów administracji publicznej w procedurze wydawania decyzji o środowiskowych uwarunkowaniach przedsięwzięcia, w: Bartosz Rakoczy (red.), Oceny oddziatywania na środowisko w praktyce, Wolters Kluwer, Warszawa 2017, s. $117-118$.

Tuszko Aleksander, Gospodarka wodna a środowisko, Ludowa Spółdzielnia Wydawnicza, Warszawa 1984, s. 16.

Ura Elżbieta, Stelmasiak Jerzy, Pieprzny Stanisław (red.), Ocena modelu prawnego organizacji ochrony środowiska w Polsce i na Słowacji, Wydawnictwo RS Druk, Rzeszów 2012, s. 281. 
Verschuuren Jonathan, The Dutch Crisis and Recovery Act: Economic Recovery and Legal Crisis?, Potchefstroom Electronic Law Journal 2010/13/5, s. 198.

Walas Martyna, Organy i stużby ochrony wód, w: Bartosz Rakoczy (red.), Wybrane problemy prawa wodnego, Wolters Kluwer, Warszawa 2013, s. 265-288.

Zachariasz Igor, Komentarz do art. 24 ustawy o planowaniu i zagospodarowaniu przestrzennym, LEX 2017.

Zimmermann Jan, Prawo administracyjne, Wolters Kluwer, Warszawa 2014, s. 142-144, 148-152.

\section{Orzeczenia}

Wyrok TK z dnia 6 grudnia 2011 r., sygn. akt SK 3/11, OTK ZU nr 10/A/2011, poz. 113. Wyrok WSA z Warszawy z dnia 5 maja 2008 r., sygn. akt IV SA/Wa 372/08, LEX nr 506934.

Kamila SOBIERAJ

\section{ESTABLISHING OF THE STATE WATER FARM "POLISH WATERS" AS AN EFFECT OF THE PUBLIC AUTHORITIES TASKS AND COMPETENCES ACCUMULATION IN THE FIELD OF WATER MANAGEMENT - SELECTED ISSUES}

( Sum mary)

The Act of 20.07.2017 - Water Law, which entered into force on January 1, 2018, introduced a change in the organizational and legal structure as well as the division of public authorities tasks and competences regarding water management. A new structure was established - the State Water Farm "Polish Waters" (PW). PW are an unified institutional structure, which replaced, as a rule, the authorities previously operating in the area of water management and focused a wide group of specialized and profiled tasks and competences in that area. Several types of tasks and competences in the area of water management being previously dispersed among many authorities and entrusted in large part to general public authorities were concentrated.

The aim of this article is to analyze the selected tasks and competences in the field of water management that were concentrated: issuing of water law permits and cumulating in PW's hands of the issues requiring highly specialized knowledge regarding water management, which can occur in other proceedings.

The article aims to show that while these changes undoubtedly may be important for streamlining and accelerating the investment process in the area of water management, the existence of certain ambiguities, imprecision between the rules, their mutual inconsistency may result in problems for authorities and investors obliged to use them, and therefore, the degree of achieving the intended effect may be smaller. It is also reasonable to introduce some additional regulations.

Keywords: specialized authorities; public tasks; public administration activities effectiveness 